\title{
Beyond Sindell: Relaxation of Cause-in-Fact Rules for Indeterminate Plaintiffs
}

Richard Delgado

University of Alabama - School of Law, rdelgado@law.ua.edu

\section{Recommended Citation}

Richard Delgado, Beyond Sindell: Relaxation of Cause-in-Fact Rules for Indeterminate Plaintiffs, (2012). Available at: https://scholarship.law.ua.edu/fac_working_papers/239

This Working Paper is brought to you for free and open access by the Faculty Scholarship at Alabama Law Scholarly Commons. It has been accepted for inclusion in Working Papers by an authorized administrator of Alabama Law Scholarly Commons. 


\title{
FOR EDUCATIONAL USE ONLY
}

70 Cal. L. Rev. 881

California Law Review

July, 1982

\begin{abstract}
*881 BEYOND SINDELL: RELAXATION OF CAUSE-IN-FACT RULES FOR INDETERMINATE PLAINTIFFS
\end{abstract}

\author{
Richard Delgado [FNa] \\ Copyright 1982 by the California Law Review, Inc.; Richard Delgado
}

\section{INTRODUCTION}

Tort law has developed a number of creative doctrines to aid plaintiffs who are unable, through no fault of their own, to identify the causes in fact of their injuries. [FN1] Thus, when a defendant's negligent conduct unites with another force to injure the plaintiff, the defendant will be held liable if his or her conduct contributes materially and substantially to the injury. [FN2] Liability is also imposed when the conduct of multiple defendants is simultaneous but does not combine. [FN3] In Summers v. Tice, [FN4] for example, the plaintiff suffered injury at the hands of one of two hunters, both of whom fired negligently in his direction. To aid the faultless plaintiff, the court shifted the burden of proof onto each hunter to prove that he was not responsible for the plaintiff's single injury. [FN5] Similarly, patients who have suffered from the malpractice $\boldsymbol{*} \mathbf{8 8 2}$ of an unknown member of a medical team have been permitted to recover from each member who could not demonstrate his or her own freedom from fault. [FN6]

These doctrines have been widely followed and approved, and seem unlikely to be abandoned. Indeed, the California Supreme Court, in Sindell v. Abbott Laboratories, [FN7] recently extended the principle of Summers $v$. Tice to a suit against nine defendants. The plaintiff, a cancer victim whose mother had ingested DES when pregnant with her, was unable to present evidence linking her injury to a particular drug manufacturer. She thus sued the major manufacturers of DES, arguing that each should bear the burden of proving that it had not produced the drugs the mother ingested. The court upheld her suit as an extention of Summers and, when many of the manufacturers were unable to absolve themselves, held each liable in proportion to its share of the DES market. [FN8]

These developments aid plaintiffs confronted with uncertainty over the defendant or defendant-class-plaintiffs who know they have been injured, but not by whom. In Sindell, the plaintiff knew that she had suffered injury as a result of the negligence of another and was entitled to recover. What she did not know was which of nine drug manufacturers was responsible. Suppose the places are reversed-that Mrs. Sindell is one of nine (or some other number of) individuals, some of whom have been injured by the negligence of a single defendant, but who are unable to determine which among them has suffered injury at the defendant's hands. Their inability might result from a long latency period, [FN9] or technological problems in separating out the contribution of $* \mathbf{8 8 3}$ natural factors, such as aging, radiation, or genetic predisposition. [FN10] Nevertheless, they may know with scientific and legal certainty that defendant's conduct has injured some of them. [FN11] Should a "reverse-Sindell" doctrine aid plaintiffs in the mirror image situation in which uncertainty lies not in the defendant class, but in the plaintiff class?

This Article will explore the feasibility and desirability of extending tort theories to permit recovery in the reverse-Sindell situation. The principal barrier facing "indeterminate plaintiffs" is the requirement of causation in fact-the rule that in a tort suit, the plaintiff must show that defendant's conduct contributed to his or her injury. Although the plaintiffs in Summers and Sindell could not prove causation in fact, the court in each situation devised a rule that enabled 
the plaintiff to remain in court. Should a similar extension take place when the uncertainty concerns not the origin or starting point of causation, but its terminus? [FN12]

The extension, if it occurs, is likely to prove particularly useful in cases of biological causation, in which an injury may develop years after exposure, [FN13] or in suits for damage to property, such as pitted windshields exposed to noxious chemicals, dust, or gravel. [FN14] But rather than emphasizing particular forms of causation (cancer causation, for example), this Article will examine two general paradigms of indeterminacy. The first Section describes the two paradigms and analyzes $* \mathbf{8 8 4}$ them under current causation doctrine to determine the extent to which existing law affords relief for indeterminate plaintiffs. Finding that current law inadequately protects persons against victimization in situations when the defendant is identifiable but the plaintiff is not, this Article next evaluates policy grounds for developing new doctrine. After determining that public policy favors the development of new doctrine, this Article discusses alternative mechanisms by which courts might afford relief. A final section identifies objections that could be made to the development of rules designed to address problems of indeterminacy in the plaintiff class, and offers answers to those objections.

\section{CAUSAL INDETERMINACY IN THE PLAINTIFF CLASS}

The imagination can create endless fact patterns which include indeterminate plaintiffs. For simplicity's sake, this Article focuses on two patterns: cases of statistically proved causation, and cases in which causation is mechanically proved. In both cases, modern tort rules deny recovery because plaintiffs are unable to meet causation requirements.

\section{A. Two Paradigms}

The first paradigm or example may be labelled "statistically proved causation." Suppose that a person or corporation moves to a region and begins to release a force or substance [FN15] known to cause injuries of a certain type. The injuries are not unique to the force or substance; they also occur naturally. Moreover, the injuries are causally indistinguishable-experts cannot determine whether a case arises from culpable human causes or nonculpable natural causes. [FN16] Further, $* \mathbf{8 8 5}$ the culpable and nonculpable causes do not synergize each other: subthreshhold amounts of each do not combine to cause injury. [FN17] No other human agent releases the force or substances.

Before the defendant's arrival, the region experienced a stable ("background") rate of 100 cases of the injury per year. [FN18] After the defendant's arrival, the number of cases increases to 190 and remains constant. Expert testimony establishes that the increased incidence of the injury can only be attributed to the conduct of the defendant. [FN19] In $* \mathbf{8 8 6}$ such a case, injury to the class will be "statistically proved." [FN20]

The second paradigm is that of "mechanically proved causation." It requires simultaneously acting forces, one natural, the other human, each causing a known number of undifferentiable injuries. [FN21] For example, imagine that two hikers walk along the base of a rocky cliff. A third person negligently throws a stone in their direction at the same moment that a loose stone of the same description falls from the cliff. Both hikers suffer identical injuries. The evidence establishes that the thrown rock produced one injury, the falling rock the other, but it is impossible to determine whose injury resulted from which cause. [FN22] In this example, the occurrence of a single culpable injury is "mechanically proved."

\section{B. The Paradigms Under Current Causation Law}

Even though it may be known with certainty (as in the second example) or with an extremely high probability (as in the first) that the defendant is responsible for injuries to one or more members of the victimized class, causation rules make it unlikely that any of the victims will recover. [FN23] In general, the plaintiff must plead and prove causation-in-fact. [FN24] 
There are two tests in common use. The "but-for" test, under $* \mathbf{8 8 7}$ which the plaintiff must establish that without defendant's actions the injury would not have occurred, is the most frequently employed test. [FN25] A "material and contributing factor" test, which requires that plaintiff only show that the defendant's conduct contributed to his or her injury, is applied in some jurisdictions in cases of mixed causation. [FN26]

Our paradigms satisfy neither test. The "but-for" test is not met because other factors, acting independently, may have produced the injury. The "material and contributing factor" test is also unsatisfied because the factors operate separately and do not combine. Direct proof of causation is therefore impossible. [FN27] Circumstantial proof also fails because no victim can make it appear more probable than not that his or her injury stemmed from defendant's conduct. In Paradigm I, the proportion of culpably to nonculpably caused injuries is less than half (90 cases out of 190); in Paradigm II, the proportion is one-half. [FN28] Unless causation rules are modified, defendants should win a series of summary judgments.

A number of exceptions and special doctrines have been created to mitigate the harshness of the "but-for" and "material factor" tests. Many are designed to assist plaintiffs in situations, like ours, of multiple causation. Although these special rules indicate a generalized flexibility and willingness to accommodate new categories of plaintiffs where justice demands, none seem capable of being applied to our paradigms. When the independent or concerted conduct of two human actors harms a plaintiff, a number of doctrines, including that of Summers v. Tice, aid the plaintiff who is unable to trace causation to a single defendant. [FN29] But when one of two alternative causes is nonhuman, the plaintiff must prove causation by a preponderance of the evidence; there will be no shifting of the burden of proof. [FN30]

$* \mathbf{8 8 8}$ Theories of strict liability, negligence per se, or violation of statute are similarly unhelpful, as all require proof of causation. [FN31] Res ipsa loquitur might seem promising, since it enables the plaintiff to benefit from inferences that defendant was negligent and that the defendant's conduct was the cause of plaintiff's injury. [FN32] But res ipsa loquitur is not available to individual plaintiffs in our paradigms because they cannot show that their injury is of a type that does not occur without negligence. [FN33]

A number of foreign and American courts have permitted plaintiffs to use statistical or epidemiological evidence to establish that their injuries resulted from a given cause, such as exposure to a carcinogen. [FN34] But this form of proof cannot help the plaintiffs in the two situations under discussion. Such evidence would be useless for the "mechanically proved" causation of the second paradigm. In the first paradigm, statistics only enable a plaintiff to prove that the defendant is responsible for an increased number of victims. They do not help the plaintiff prove that he or she is a victim. [FN35] Individual suits will fail, because natural causes preponderate-are more causally efficacious than the human causes-and there is no way to distinguish naturally-caused injuries from ones caused by human action. No plaintiff will thus be able to prove that his or her injury was probably caused by the defendant.

It is tempting to think that joinder devices, such as class suits, may offer relief. In each paradigm, a class is in a sense "injured"-known to contain victims of defendant's action. But a class suit is no more useful than a series of individual suits, at least until the doctrinal $* \mathbf{8 8 9}$ problems of causation are resolved. In a class suit, the representative must have a claim typical of the class. [FN36] Under current law, however, the typical claim of a class member is a losing claim. Thus, a court should dismiss the claim and decertify the class. A further requirement is that the boundaries of the aggrieved class be ascertainable with reasonable certainty. [FN37] In our cases, this is impossible, since persons may be injured by defendant without realizing it. A class suit is thus no more promising than a series of individual suits. Permissive joinder rules [FN38] might allow plaintiffs to join forces at the pleading stage but would not protect them against dismissal or summary judgment when it became obvious that their individual claims were not maintainable.

A group of decisions known as "destruction of a chance" cases [FN39] comes closer to accommodating our paradigms, but also fails. In destruction of a chance cases, the plaintiff cannot trace the causation of his or her injury to defendant, but is permitted to recover if he or she can show that the defendant's action made a bad situation worse. A patient, for example, may have a $25 \%$ chance for survival without an operation and a $40 \%$ chance with a properly performed operation. If the operation were not properly performed, some courts would uphold 
causes of action in negligence for this deprivation, on the theory that it is the loss of a chance, not the death, that is compensated. [FN40]

Although superficially similar, these decisions do not reach the cases under consideration. In our first paradigm, each of the 190 members of the injured class suffers injury because of one of two factors causing harm. In this respect, the claim is similar to that of the surgical patient, who is both sick and the victim of medical malpractice. But unlike the surgical victim, the persons in our paradigm do not know that human causes are responsible, even in part, for their injury; they merely suspect it. As a whole, the class of 190 persons has suffered the loss of a chance-the chance to have the usual complement of 100 members. But it would require major extension of notions of standing and legal rights to permit classes to sue for such harms. Occam's Razor suggests that conceptually simpler means be found if possible. [FN41] As *890 will be seen, simpler means are indeed at hand. [FN42]

The only judicial statements that directly support plaintiffs in our category are found in foreign cases which are no longer followed or were never fully recognized. For example, an English court in a 1946 case, Vyner v. Waldenberg Bros. Ltd., [FN43] held that the breach of a safety provision would shift the burden of proving causation of a work-related injury onto the defendant employer. The case, however, was overruled 10 years later by a unanimous House of Lords. [FN44] Similarly, a Canadian court in Cook v. Lewis, [FN45] a two-hunter case similar to Summers v. Tice, declared that a defendant who negligently "intermixed" human causation with natural causation so as to destroy the plaintiff's "power of proof" would bear the burden of disproof on the issue of causation. [FN46] The statement was dictum, however, as both causes in the case were human agents.

In the United States, a number of statutes have been enacted to address technologically induced injuries of the general type we are considering. [FN47] Relatively few provide for compensation, however, [FN48] and all require proof of causation before the plaintiff is entitled to any remedy. [FN49] The Price-Anderson Act, for example, which imposes strict liability for radiation-based injuries, requires that a claimant demonstrate that his or her injury resulted from the accident in question. [FN50] A few statutes soften the requirement of proof by means of presumptions. [FN51]

These occasional statutory innovations and foreign decisions are, $* \mathbf{8 9 1}$ at best, straws in the wind. American case and statutory law has not yet changed to accommodate injuries to classes the identity of whose members is unknown. The main grounds for hope lie in the "exceptional" categories that have been carved out to aid particular classes of victims confronted with uncertainty with respect to the defendant class. [FN52] These exceptions, responsive to considerations of policy and fairness, [FN53] now accommodate cases of alternative and enterprise liability, concerted action, "common goal," and certain categories of sheer necessity. [FN54] It would seem that if equally valid policy grounds exist on behalf of indeterminate plaintiffs, a further extension is warranted. [FN55] The next section considers policy reasons that support such an extension.

\section{TORT POLICIES AND EXTENSION SINDELL TO INDETERMINATE PLAINTIFFS}

On its face a simple, mechanical formula requiring only a finding of physical fact, the requirement of but-for causation is in reality a contextual, policy-sensitive instrument. [FN56] This policy orientation is evidenced by the numerous exceptional categories, [FN57] but it is also visible in the way courts apply the doctrine in ordinary cases. Malone, [FN58] Green, [FN59] Keeton, [FN60] and Prosser [FN61] purport to find a sliding-scale approach, in which courts apply the causation-in-fact requirement with decreasing stringency as the equities or public policies increasingly favor recovery. Commentators of the law and economics school have $* \mathbf{8 9 2}$ found causation-in-fact of such slight value in promoting classic tort goals that it might as well be replaced by general principles of economic efficiency. [FN62]

Other writers, such as Gelpe and Tarlock, have argued that the purposes of particular areas of the law, such as environmental protection, would be furthered by softening the requirement 
of causation-in-fact or reducing the burden of proof below the standard of more probable than not. [FN63] Weinrib has asked why retention of the requirement as an aspect of plaintiff's case is necessary, suggesting that in appropriate cases, the requirement might be shifted onto the defendant. [FN64] The policy orientation that surrounds causation-in-fact makes it likely that a court asked to extend Sindell-Summers reasoning to indeterminate plaintiffs would evaluate the request at least partly in policy terms. Such an examination would consider the extent to which relaxation of causal rules would promote tort goals of compensation, loss spreading, deterrence, economic efficiency, knowledge generation, and justice. [FN65]

\section{A. Compensation}

A central purpose of tort law is to compensate victims. Extending Sindell-Summers doctrine to indeterminate plaintiffs would promote this goal, although in a somewhat uneven or inexact manner. If all members of the plaintiff class are permitted to recover fully, many will receive possibly substantial awards even though the defendant did not injure them. One solution is to provide only proportional recovery, [FN66] in which each member of the plaintiff class is compensated in proportion to the damages sustained by the class as a whole. This method of distributing damages undercompensates some victims while overcompensating others, a result some class members will see as unfair. The only plausible alternative, however, is that provided under present rules - no $* \mathbf{8 9 3}$ recovery at all. [FN67]

Relaxation of the burden of proof with respect to causation [FN68] would be more attractive to plaintiffs, of course. A similar modification has occurred in selected areas, such as Title VII litigation. [FN69] But the hope for such an extension to environmental suits seems unrealistic. Suits for damages in both paradigms, though meritorious, are not supported by the powerful historical and ideological policies against racial discrimination. Moreover, they would be resisted by defendants on the ground that they would impose "crushing liability" far beyond the damage actually caused by their actions.

The modification proposed permits recovery corresponding to the damage actually done, and thereby achieves a form of rough-hewn justice. All the persons who suffered injury after exposure to the agent recover something, though less than what they would recover by establishing that causation was probable. No one recovers who does not suffer an injury of the kind caused by defendant's conduct, and who was not placed at risk by the defendant's acts. [FN70] The extension thus promotes the goal of compensating victims, although the promotion is less than perfect.

\section{B. Loss Spreading, Deterrence, and Economic Efficiency}

From the viewpoint of the plaintiff who seeks complete compensation, the proposed scheme of proportional recovery operates imperfectly. From the defendant's perspective, however, the fit of certain policies is perfect. Loss spreading [FN71] is advanced without the inexactness found in connection with compensation. The plaintiff class passes the exact amount of accident costs on to the defendant, who can then pass this amount on to the public through additional charges or insurance. At the same time, the increased costs deter the defendant from engaging in the liability generating practice. The in terrorem effect is tailored to the deed; there is neither over- nor under-deterrence. Unlike*894 its effect on compensation, the extension of the Sindell-Summers rule strongly promotes the tort goals of loss spreading and deterrence.

For the same reasons, the extension of Sindell-Summers reasoning to the case of indeterminate plaintiffs advances the goal of economic efficiency. [FN72] Tortfeasors will face potential liability corresponding to the damages they cause the public. Where injuries are avoidable at lower cost by taking safety precautions, tortfeasors will have an incentive to do so. A new rule permitting liability in the two paradigms thus encourages businesses and individuals to act to maximize economic wealth and social welfare. [FN73]

C. Knowledge and Justice 
The extension of Sindell and Summers to cases of indeterminate plaintiffs should also have a beneficial knowledge generating effect. [FN74] At present, inability to trace causation aids defendants, who consequently lack incentive to carry out research into injury causation. Imposing liability on defendants encourages them to investigate the manner in which their actions endanger others so that they may escape liability by showing that they are not to blame. It is possible to argue that plaintiffs have an equal stake in avoiding injury and that the cost of developing knowledge about mechanical or biological causation should be placed on them. Ordinarily, however, the defendant-disseminator will have greater access to the information and technology necessary to develop this knowledge, and will be in a position to do so more cheaply than members of the public. The burden is thus appropriately $* \mathbf{8 9 5}$ placed on him or her. [FN75]

Once it is seen that extension of Sindell's cause-in-fact treatment to indeterminate plaintiffs serves goals of compensation, deterrence, economic efficiency, and knowledge generation, the conclusion seems inescapable that such an extension is morally just. [FN76] Existing causation rules allow a blameworthy party to escape liability. The proposed modification imposes liability and compensates victims in proportion to the likelihood that they were, individually, injured by the defendant. Faced with a choice between manifest injustice and inexact justice, the law should prefer the latter. [FN77]

\section{*896 III}

\section{THEORIES AND MECHANISMS OF RELIEF}

If tort policies and parallel reasoning support extension of the Sindell-Summers result to situations in which uncertainty lies in the plaintiff class, how might such a reform be effected? Two approaches seem possible. In the first, existing tort mechanisms are manipulated to accomplish the desired result. In the second, a new mechanism is created. Although both approaches have merit, this Article urges courts to adopt a new mechanism.

\section{A. Modification or Extension of Existing Mechanisms}

Courts may accommodate suits brought by plaintiffs in indeterminate classes by modifying or extending existing mechanisms. They could, for example, find that exposure to certain forms of risk is a harm in itself, thus avoiding causal problems entirely. [FN78] Thus, when the plaintiff knows of the exposure and suffers fear and anxiety, recovery could be permitted for negligent or intentional infliction of emotional distress. [FN79] Second, courts could shift the burden of proof to the defendant* $\mathbf{8 9 7}$ once risk-creation plus harm is shown, as was done in a leading English case. [FN80] More drastically, they could "estop" the defendant from denying causation once his or her negligent conduct and materialization of the harm are shown. [FN81]

Courts could also lower the burden of proof where the defendant's action appears especially reprehensible, so as to allow plaintiffs to recover by showing that causation is possible, or conceivable, rather than probable. [FN82] They could hold plaintiffs "vicariously compensable," by $* \mathbf{8 9 8}$ analogy to the concepts of transferred intent or vicarious liability, [FN83] thereby permitting recovery on a showing that causation exists with respect to some member of the plaintiff class. If through jury nullification, [FN84] a jury finds the defendant liable in one of our paradigm cases and awards punitive damages, the court might condition the award on plaintiff's willingness to share it with other similarly situated victims, [FN85] or might use it to benefit the injured class. [FN86]

Finally, all or most of the claims of the indeterminately bounded class might be assigned to a given individual or proxy, who would sue for the known number of claims in return for a promise to distribute any recovery. [FN87] Subrogation could create the same result. Consider, for example, a large health insurance carrier forced to pay the medical expenses of all 190 victims in our first paradigm. The carrier can argue that it is entitled to sue and to be compensated for the 90 additional $* 899$ cases, even without specific identification of the victims. [FN88] 
All these approaches are promising, and could be adapted by a court to provide a method of recovery for indeterminate plaintiffs. [FN89] Some have the drawback that they stretch existing doctrine to a possibly undesirable extent. Others permit overcompensation and "crushing liability" [FN90] against the defendant which exceeds the amount of damages actually caused.

\section{B. The Proposed Solution}

The best solution would combine the elements of the second and final approaches described above. When a defendant has caused a known number of injuries to a class, as in one of the paradigm situations, the burden of proof should be reversed, and the defendant should be required to prove noncausation with respect to each injury. [FN91] The "prima facie case" that plaintiff must satisfy to obtain the described relaxation of causal rules consists of the following elements: (i) that $\mathbf{*} \mathbf{9 0 0}$ plaintiffs have suffered an injury; (ii) that the injury be one that could have resulted from either natural or human causes, acting separately and without synergy; (iii) that the injuries be causally indeterminate-that is, not identifiable as humanly or naturally caused; (iv) that the defendant is the only possible human cause; and ( $v$ ) that the population injured, mode of risk, and other variables be uniform and stable enough to permit calculation of the increased number of victims. Once the plaintiff has established the prima facie case, the burden of proof shifts to the defendant to prove noncausation with respect to each injury. If he or she fails to do so, liability will be imposed for the number of unproved victims. The defendant will be able to shoulder this burden of proof in one of two ways. First, he or she can show the plaintiff's calculation of the number of humanly caused cases is exaggerated. [FN92] This would reduce his or her liability in proportion to the reduction in number of victims. Second, he or she can show that there is another human defendant who has injured some of the victims. [FN93]

In return for relaxation of the causation requirement, a plaintiff will be required to share any recovery with the other members of the class. [FN94] The named plaintiff would thus prosecute a representative suit, and would be bound by the rules normally applied in such cases, including a fiduciary relationship to the class members. [FN95] The plaintiff $* \mathbf{9 0 1}$ class, if successful, would recover an amount corresponding to its combined losses attributed to defendant's actions. This amount would be allocated among the members pro rata, after subtracting litigation costs. [FN96] Even if damages vary greatly from one class member to another, or cannot be known precisely, established methods exist for ensuring just compensation to each class member. [FN97]

From the defendant's perspective, the result corresponds exactly to the harm created and cannot reasonably be viewed as unfair. [FN98] From the perspective of the plaintiff, the scheme compensates all who suffer the injury and who were within the zone of risk. [FN99] Society as a whole $* \mathbf{9 0 2}$ benefits because of the deterrent effect of the tort sanction, and because defendants are no longer permitted to expose others to injury with impunity merely because causation is difficult or impossible to trace. Tortfeasors, particularly corporate ones, will have an incentive to carry out research that will permit them to carry the burden of disproof on the issue of causation, thus avoiding liability. Once the specific mechanism of causation is known, it may be possible to reduce the risk or even eliminate it entirely.

\section{OBJECTIONS TO THE PROPOSED SOLUTION}

The conclusion that there ought to be compensation for indeterminate plaintiffs and the method by which it is reached are mirror images to those in Sindell. In both cases, modification of causation rules avoids technological impossibility of proof, while the practical difficulties of calculating liability or distributing relief are circumvented by proration. Similar policy grounds support both extensions.

Because the two reforms stand on similar footings, this section omits any discussion of criticisms that can be levelled at both Sindell and the proposed companion remedy. For example, no attention is given to the objections that both "open the floodgates" of liability, 
[FN100] violate due process, [FN101] or unduly burden entrepeneurial activity. [FN102] Nor is there discussion of the objection that both problems are best left to an administrative remedy or a scheme of social insurance. [FN103] These aspects of Sindell have already spurred a lively body of commentary; some of them were discussed in the opinion itself. Sindell seems likely to survive them. For the sake of economy, I assume the viability of $* \mathbf{9 0 3}$ Sindell and the proposed modification in the face of all common objections.

A number of objections do affect the argument for modified causation rules for plaintiffs uniquely, however, or at any rate more forcefully than when applied to Sindell alone, and therefore merit separate consideration. These objections include: (i) that the remedy imposes liability on defendants who are non-negligent vis-a-vis plaintiffs, i.e., because of risk-creation simpliciter; (ii) that the remedy contravenes doctrine and policy forbidding liability based on probabilistic evidence; (iii) that the fact situations (Paradigms I and II) that call for application of a reverse-Sindell rule are unlikely to be found in the real world; and (iv) that Sindell and our remedy could be combined, resulting in liability of multiple defendants toward multiple plaintiffs, and virtually endless liability.

\section{A. Compensation for Plaintiffs not Demonstrably Injured by Defendant's Actions}

It is a basic principle of tort law that the plaintiff must show that the defendant injured him or her. [FN104] The Anglo-American system does not award damages simply because a defendant has done something reprehensible, created a risk, or behaved irresponsibly. [FN105] It could be argued that an award of damages to indeterminate plaintiffs would violate this principle by compensating individuals who cannot show that they have been injured by the defendant, or, indeed, by any human being at all. In Sindell, the court permitted the plaintiff to recover against drug manufacturers, many of whom did not injure her, because of overriding policy grounds favoring recovery. [FN106]

But overlooking causal indeterminacy for plaintiffs may seem a more radical departure than permitting recovery for known plaintiffs against indeterminate defendants, because an indeterminate plaintiff may well have no reason to deserve recompense. Sindell deserved compensation; her problem was that she did not know who had injured her, and thus did not know from whom she was entitled to recover. This may appear a less serious problem than that confronting indeterminate plaintiffs, who cannot prove that they belong in court-that $* \mathbf{9 0 4}$ they have a cause of action at all. [FN107]

A number of responses seem possible. First, the defendants in each of our paradigms unquestionably injured members of the plaintiff class; plaintiffs cannot use the proposed remedy unless they first establish this. Defendants are thus not penalized for risk creation alone, as they have demonstrably injured a number of victims. Further, the plaintiffs' inability to trace causation and thus identify which of their number were injured by the defendant is a result of defendant's action, rather than any failure on the part of plaintiffs to investigate and develop their case. Every plaintiff will be highly motivated to trace causation and thus recover a full, rather than a partial, share of the damages. [FN108] Reverse-Sindell suits will be filed only when a conventional suit is not feasible.

Finally, the proposed remedy gives only partial relief to members of the indeterminate plaintiff class. The amount of each plaintiff's recovery is measured by the proportion of culpably injured to nonculpably injured members of the class. If a class contains only a small proportion of culpably injured victims, each member will recover only a small amount. If the class contains a high proportion, each member will receive an award approximating his or her actual damages. Any unfairness or "windfall" effect is mitigated by this pro rata scheme of distributing damages. [FN109] Classes that contain a high proportion of "deserving" plaintiffs will be in a position to provide each member with nearly full compensation. Classes composed of a high proportion of "undeserving" plaintiffs will recover only a small amount.

\section{B. Probabilistic Evidence}

A second objection to a reverse-Sindell rule is that it awards damages on the basis of probabilistic evidence. [FN110] Of course, only one of the paradigms under consideration 
presupposes the use of probabilistic evidence. In the second paradigm, the plaintiff proves causation mechanically; probability theory plays no part.

The first paradigm does entail the use of statistical evidence, but $* \mathbf{9 0 5}$ only to establish the number of culpably injured members of the plaintiff class. The comparison of before and after frequencies that the model entails thus presents few of the dangers that courts fear in connection with probabilistic evidence and that have on occasion led them to exclude it. Probabilities are not used to single out the defendant [FN111] nor to establish a causal link between conduct of a certain type and a particular injury. [FN112] There is little risk that judge and jury will be paralyzed by obscure arguments or calculations. [FN113] Unlike identification cases, there is little danger that the jury will apply a probability coefficient to the wrong population or variable, [FN114] or that plaintiffs will deliberately use statistics to conceal a weak case. [FN115] The danger of dependent variables masquerading as independent is minimal. [FN116] Thus, the arguments against the use of probability evidence do not apply to the paradigms under discussion.

\section{A Model Without Application?}

A further objection that might be made to new causation rules for $* \mathbf{9 0 6}$ indeterminate plaintiffs is that there would be few, if any, applications for them. [FN117] If so, their proposal would be little more than an exercise in symmetrical reasoning. It is probably true that the number of Paradigm II cases that are likely to arise is not large. When an injury is mechanically caused, it will often be possible for the plaintiff to eliminate natural causation and make a case for human liability. Mechanical forces generally operate quickly and without a latency period or complex physiological mediating mechanisms to obscure cause and effect. In these cases, we properly expect the plaintiff to make his or her case under conventional rules. [FN118] Indeed, most plaintiffs will prefer to do so in order to obtain full, rather than proportional, relief.

[FN119]

Some Paradigm II cases do seem likely to arise; witness the recent "Medfly" spraying cases. [FN120] Moreover, even if Paradigm II cases arise only rarely their infrequency is not a good reason for courts to refuse them careful consideration when appropriate examples come before them. Summers v. Tice, the defendant-side analog of Paradigm II, was an "unusual" case when it was decided, as was Sindell. This was no reason for denying the Summers and Sindell plaintiffs relief.

Paradigm I cases [FN121] are likely to arise somewhat more often. The principal difficulties will arise from the requirements that there be only one possible human cause, and that the population, mode of risk, and other variables be stable enough to permit a statistical calculation of the increased number of injuries above a background level. Such a suit will be impossible if, for example, the population is shifting or highly mobile, or if the background rate of the disease or injury varies greatly. A Paradigm I suit will also be barred if there is not one but a multitude of potential human defendants, as might be the case in a region that $* 907$ contains several polluters. [FN122]

The requirements of Paradigm I would be most easily satisfied in connection with immobile or "captive" populations, such as members of a workforce, inmates of a mental or penal institution, students at a school, or residents of small, isolated communities. [FN123] Uniformity of exposure could be met if it appeared that each individual suffered a common risk, for example from airborne distribution of a harmful substance in a confined area or contamination of food or water supply. [FN124] The requirement of a single human defendant not only preserves doctrinal symmetry but also guards against inordinate expansion of the lawsuit and the spectre of undeserving plaintiffs recovering from defendants who were not personally responsible for their injuries. These requirements would thus tend to assure that Paradigm I suits would be manageable both in number and in size. [FN125]

Sindell, however, permitted a suit against a class of multiple defendants. This raises a final objection-that extending tort compensation to indeterminate plaintiffs would inexorably combine with existing theory to permit causes of action against indeterminate defendants. The ultimate result might be open-ended liability, with damages exceeding anything the legal system has hitherto known. 


\section{Combining Both Theories: Indeterminate Plaintiffs Versus Indeterminate Defendants}

If causation rules are relaxed for indeterminate plaintiffs, the sobering possibility exists that ingenious counsel will combine both the Sindell doctrine and its inverse in a suit by a class of indeterminate plaintiffs against a class of indeterminate defendants. Imagine, for example, several manufacturers which, acting independently, market an identical substance known to cause a certain type of injury. The injury also occurs naturally, so that its occurrence does not in itself implicate any of the manufacturers. A substantial rise in the incidence of the injury immediately follows. Investigation eliminates other possible causes of the increase.

*908 Neither the Sindell nor the reverse-Sindell doctrine will apply. [FN126] But there seems to exist no theoretical reason not to permit a plaintiff to unite both principles and thus launch a massive lawsuit presenting complex problems of proof and requiring a large investment of judicial resources. The distribution of any damage award would be an accountant's nightmare, requiring proration with respect to both the defendant and plaintiff classes. Because of the high costs and special dangers of such suits, [FN127] courts may well refuse to hear them at least until there has been an adequate period of experimentation with both types of Sindell causation rules.

\section{CONCLUSION}

The development of special cause-in-fact rules to aid plaintiffs confronted with indeterminacy in the defendant class suggests that a similar modification might occur when indeterminacy lies in the plaintiff class. Although current law does not permit recovery when the defendant is identifiable but the specific plaintiffs are not, many of the same considerations that supported recovery in Summers v. Tice and in Sindell v. Abbott Laboratories support it here. Permitting indeterminate plaintiffs to sue for their injuries promotes tort goals of compensation, deterrence, efficiency, knowledge generation, and justice. Distribution of damages can be accomplished by a variety of allocation schemes, employing a form of proportional recovery. This extension is maintainable in the face of objections that it would compensate persons who do not deserve it, would award damages based on probabilistic evidence, and would be available either too rarely or too often. It would eliminate an existing asymmetry in causal doctrine, and would advance the policy objectives of the substantive areas in which it is likely to be applied.

Modified tort rules for indeterminate plaintiffs are thus a logical and desirable next step in the development of tort doctrine.

[FNa] Professor of Law, University of California at Los Angeles. J.D. 1974, University of California, Berkeley. I gratefully acknowledge the contributions of the many persons who read drafts of this Article or who in conversation offered insights, criticism, or comments that helped deepen my understanding of causation-in-fact rules and their possible modification in the novel contexts discussed herein: Michael Alexander; Jan Almquist, member of the California Bar; Alan Brownstein, Professor of Law, UC Davis Law School; Jean Love, Professor of Law, UC Davis Law School; Peter McAllen, Law Clerk, Ninth Circuit Court of Appeals; Wex Malone, Professor of Law, Emeritus, LSU Law School; and Gary Schwartz, Professor of Law, UCLA Law School.

[FN1]. Cause-in-fact is defined and illustrated infra Part I, Section B. In general, the term refers to the legal requirement that the defendant's conduct caused the plaintiff's harm. W. PROSSER, HANDBOOK OF THE LAW OF TORTS 237 (4th ed. 1971) [hereinafter cited as W. PROSSER, TORTS]; Prosser, Proximate Cause in California, 38 CALIF. L. REV. 369, 375 (1950) ("necessary antecedent . . . something without which the event would not have occurred") [hereinafter cited as Prosser, Proximate Cause]. See also J. FLEMING, THE LAW OF TORTS 179-85 (5th ed. 1977).

While the following substantive developments in causation rules have taken place, procedural innovations have occurred that have also eased the burden of the plaintiff who is initially unable to identify the individual who has injured him or her. These include notice pleading, liberal rules pertaining to amendment and joinder of parties, discovery, and "John Doe" complaints. 
[FN2]. RESTATEMENT (SECOND) OF TORTS §§ 431-433 (1965); id. § 876 (1979); W. PROSSER, TORTS, supra note 1 , at 240-41.

[FN3]. This situation is sometimes referred to as "alternative liability," e.g., W. PROSSER, TORTS, supra note 1 , at 243-44. See also infra notes 29-30 and accompanying text.

[FN4]. 33 Cal. 2d 80, 199 P.2d 1 (1948).

[FN5]. Id. at 88,199 P.2d at 5.

[FN6]. Ybarra v. Spangard, 25 Cal. 2d 486, 493-94, 154 P.2d 687, 691 (1944); D. LOUISELL \& H. WILLIAMS, MEDICAL MALPRACTICE १ी 14.04-.05 (1977). Compare Ybarra with Hall v. E.I. DuPont de Nemours \& Co., Inc., 345 F.Supp. 353, 386 (E.D.N.Y. 1972) (enterprise-wide liability).

[FN7]. 26 Cal. 3d 588, 607 P.2d 924, 163 Cal. Rptr. 132, cert. denied, 449 U.S. 912 (1980). The court applied an "adaptation" or "modification" of the rule in Summers, in which each defendant's responsibility for Sindell's injury was measured by its market share, id. at 603, 61011,607 P.2d at 931, 936-37, 163 Cal. Rptr. at 139, 144-45.

[FN8]. Id. at 610-13, 607 P.2d at 936-38, 163 Cal. Rptr. at 144-46. See also concert of action cases: Abel v. Eli Lilly \& Co., 94 Mich. App. 59, -, 289 N.W.2d 20, 26-27 (1979); Bichler v. Eli Lilly \& Co., No. 244 (N.Y. Ct. of Appeals, May 11, 1982); see also Henderson, Products Liability: DES Litigation, The Tidal Wave Approaches Shore, 3 CORP. L. REV. 143, 146-48 (1980); Birnbaum, Products Liability, "Concert of Action" Revisited: 2 Federal Courts Hold the Line, Nat. L.J., Oct. 12, 1981, at 37, col. 1 (DES cases reaching inconsistent results on similar facts).

In the DES cases, plaintiffs were able to establish both general causation (the tendency of DES to cause certain rare types of cancer) and negligence in the marketing and labelling of the product by the drug industry. Before Sindell, DES suits foundered on the requirement of specific causation-the rule that plaintiff must prove that a particular defendant was the one whose acts injured him or her. See generally Comment, DES and a Proposed Theory of Enterprise Liability, 46 FORDHAM L. REV. 963, 972 (1978) [hereinafter cited as Comment, Enterprise Liability] (unique problem in the DES cases concerns crucial issue of cause-in-fact).

[FN9]. "Latency period" refers to the time interval required for a causal agent to take effect. See generally Gelpe \& Tarlock, The Use of Scientific Information in Environmental Decisionmaking, 48 S. CAL. L. REV. 371, 404-05 (1974); Windscale Accident: 24-year Perspective, 120 SCI. NEWS 152 (Sept. 5, 1981) (fire in English plutonium plant in Oct., 1957 beginning to have measurable effects on health of persons exposed). In Sindell, the latency period of DES was approximately 10-12 years. 26 Cal. 3d at 594, 607 P.2d at 925, 163 Cal. Rptr. at 133.

[FN10]. See Gelpe \& Tarlock, supra note 9, at 404-05; sources cited infra note 13.

[FN11]. The various ways in which they might be able to establish this are discussed infra Part I, Section A.

[FN12]. Thus, Thode's observation that "the plaintiff's starting point on the road to a tort recovery is to be able to pick the defendant out of the crowd; that is, to demonstrate factually that there is a reason why this particular person is the defendant," Thode, Tort Analysis: DutyRisk v. Proximate Cause and the Rational Allocation of Functions Between Judge and Jury, 1977 UTAH L. REV. 1, 2, is not strictly correct. The plaintiff's starting point in some cases is to recognize himself or herself as a potential plaintiff-to pick himself or herself "out of the crowd."

[FN13]. In "biological causation," a force or substance affects the human body, with the injury or disease manifesting itself months or years later. In some such cases the force or substance 
causes a unique and easily recognizable form of injury, e.g., asbestosis. Such cases are not within the contemplation of this Article. For further examples of biological causation, see sources cited infra note 16 (Agent Orange, lead, Love Canal, radiation, cigarettes, DES, and asbestosis cases). For discussions of causation-in-fact problems in cases stemming from various types of biological injury, see generally Gelpe \& Tarlock, supra note 9, at 404-05; Katz, The Function of Tort Liability in Technology, 38 U. CIN. L. REV. 587, 616-20 (1969); Comment, Enterprise Liability, supra note 8, at 974 n.36; Soble, A Proposal for Administrative Compensation of Victims of Toxic Substance Pollution: A Model Act, 14 HARV. J. ON LEGIS. 683, 706-09 (1976).

[FN14]. E.g., Winokur, Medfly Spraying Ruining Much Area Property: $\$ 10$ Million Paid in Claims So Far With 2,700 Pending, San Francisco Examiner, Sept. 20, 1981, § B, at 1, col. 5:

Despite an evident pattern of destruction that emerged . . . when the spraying began, the chemical reaction pitting and staining car roofs . . ., fenders and plexiglass windows ... . remains a mystery.

....

Tests designed to finally identify the source of the problem currently are being conducted by the state and several insurance and auto-paint companies.

See also Capps, $\$ 28$ Million in Medfly Suits, San Francisco Examiner \& Chron., Mar. 21, 1981, at A-1, col. 2.

[FN15]. The force or substance could be: an adulterated foodstuff, radiation, environmental pollution, or a biological agent. The paradigm is not limited to "environmentally" mediated injury, although many such cases would fit within it. See examples cited infra note 16.

[FN16]. Many cases now brought, settled, or lost show aspects of Paradigm I-type indeterminacy. See In re "Agent Orange" Prod. Liab. Litig., 635 F.2d 987 (2d Cir. 1980) (circuit court affirmed district court's certification of class including all Vietnam War veterans, their families and survivors in action arising from exposure to chemical defoliant); Insurance Co. of N. Am. v. Forty-Eight Insulations, Inc., 633 F.2d 1212 (6th Cir. 1980) (asbestosis); Karjala v. Johns-Manville Prods., 523 F.2d 155 (8th Cir. 1975) (asbestosis); Reserve Mining Co. V. EPA, 514 F.2d 492 (8th Cir. 1975) (chemical wastes); Pritchard v. Liggett \& Meyers Tobacco Co., 295 F.2d 292 (3d Cir. 1961) (cigarette smoking as contributing cause of cancer); Silkwood v. Kerr McGee Corp., 485 F.Supp. 566 (W.D. Okla. 1979) (radiation injury); Sindell v. Abbott Laboratories, 26 Cal. 3d 588, 607 P.2d 924, 163 Cal. Rptr. 132, cert. denied, 449 U.S. 912 (1980) (DES); MacLeod, Family Says Poison Award Is "Too Little and Too Late", San Francisco Examiner \& Chron., Mar. 28, 1982, at B-7, col. 1 (family won large settlement against chemical company for lead poisoning); Quigg, The Nuclear Garbage Mess, San Francisco Examiner \& Chron., This World (Magazine Section), Jan. 10, 1982, at 8, col. 1 (lawsuit brought against a radioactive waste disposal business). For commentaries discussing causation problems in such cases, see U.S. DEPT. OF HEALTH, EDUCATION AND WELFARE, PUBLIC HEALTH SERVICE, THE HEALTH CONSEQUENCES OF SMOKING 131-40 (1967); Estep \& Forgotson, Legal Liability for Genetic Injuries from Radiation, 24 LA. L. REV. 1 (1963); Gelpe \& Tarlock, supra note 9, at 40405; Green, Nuclear Power: Risk, Liability and Indemnity, $71 \mathrm{MICH}$. L. REV. 479 (1973); Podgers, Toxic Time Bombs: Say Latent Disease Suits Will Be Key Battleground in ' 80 s, 67 A.B.A.J. 139, 139-41 (1981) (discussing In re "Agent Orange" Prod. Liab. Litig.); Comment, Judicial Attitudes Toward Legal and Scientific Proof of Cancer Causation, 3 COLUM. J. ENVTL. L. 344, 370 (1976) [hereinafter cited as Comment, Judicial Attitudes]; Comment, Toxic Substance Contamination: The Risk-Benefit Approach to Causation, 14 U. MICH. J.L. REF. 53 (1980) [hereinafter cited as Comment, Toxic Substance Contamination]; Manhunt for Nuclear Test Survivors, 120 SCI. NEWS 201 (1981) ( "apparent" excess of cancers in soldiers forced to participate in nuclear weapons tests conducted by U.S. government in 1945 and 1963; National Veterans Law Center is encouraging the filing of claims with Veterans Administration). See generally Garmon, The Box Within a Box Within a Box, 120 SCI. NEWS 396 (1981) (difficulty of confining radioactive wastes safely).

[FN17]. Paradigm I cases thus do not fall within alternative liability, see supra notes 3-5; infra 
notes 29-30 and accompanying text; nor within the group of cases treated under the "material contributing factor" rule, see supra note 2 ; infra notes $26-28$ and accompanying text.

[FN18]. As a corollary of this requirement, we also hypothesize that the region's population is relatively stable, with little immigration or emigration.

[FN19]. In the example given, some variation in the annual background rate would be expected. Too great an increase, however, would lead an epidemiologist to suspect that the change is not attributable to chance but rather to some new factor. If that level is represented by $100+\mathrm{N}$, then cases beyond this number are evidence of a new cause or agent. The level of confidence with which the expert would make this assertion would depend on a number of variables, such as the size of the population, the type of distribution, the stability of the population, and the magnitude and suddenness of the variation. See generally B. MCMAHON \& T. PUGH, EPIDEMIOLOGY: PRINCIPLES AND METHODS 29-46, 57-72, 157-73(1970); J. MAUSNER \& A. BAHN, EPIDEMIOLOGY 26-40, 91-109, 307-35 (1974). See also infra notes 110-16 and accompanying text (discussing objection that proposal would founder on rules forbidding use of strictly probabilistic evidence).

It is sometimes said that "one can prove anything with statistics." The law has not adopted such a hostile view. Suitably qualified statistical evidence has been admitted for a number of purposes, see sources cited infra notes 110-16 and accompanying text. Moreover, it is patently inaccurate; imagine, for example, trying to prove, with statistical evidence, that the increase in cancer and birth defects in Hiroshima and Nagasaki survivors was not caused by radiation from the A-bombing of the cities, but rather is entirely explained by postwar changes in Japanese lifestyle. The irradiation explanation simply dwarfs all other possible causal variables.

[FN20]. Two questions immediately arise: Do cases like those in Paradigm I ever occur in the real world? If so, why has tort law not yet taken account of them? Some such cases surely will arise, see infra notes 18, 136-139 and accompanying text (discussing objection that such cases will never occur). There would seem to be a number of reasons why tort doctrine has not developed doctrines to deal with them. The first is simple technological lag. After all, it was not until 1980 that Sindell was decided, even though industry-wide drug injuries began appearing as early as 1960, McBride, Thalidomide and Congenital Abnormalities, 2 LANCET 1358 (1961) (letter to the editor). Another is that it simply may not have occurred to plaintiffs and counsel that they might file suit when it could not be known with certainty that the plaintiff was culpably injured and was entitled to receive compensation, see infra notes 107-09 and accompanying text.

[FN21]. The force might include culpably caused electric shocks (occurring simultaneously with a lightning discharge), mechanical impact (occurring simultaneously with a natural event, e.g., a rock or earth slide), or flooding.

[FN22]. These facts are the inverse of those of Summers v. Tice. See supra note 4 and accompanying text.

[FN23]. As in many articles of this type, there is a tension between arguing that existing law effects relief and appealing for a new legal structure that will clearly do so. Compare infra notes 47-51, 58-62 and accompanying text (exploring elasticity in current law respecting causation) with infra notes 78-90 and accompanying text (current approaches unsatisfactory because they overextend the tort doctrines or permit duplicate recovery and "crushing liability"). See generally, Warren \& Brandeis, The Right of Privacy, 4 HARV. L. REV. 193 (1890) (tracing transition from legal protection of privacy-like interests to independent tort).

[FN24]. E.g., Sindell v. Abbott Laboratories, 26 Cal. 3d 588, 597, 607 P.2d 924, 928, 163 Cal. Rptr. 132, 136, cert. denied, 449 U.S. 912 (1980) ("We begin with the proposition that . . . the imposition of liability depends upon a showing by the plaintiff that his or her injuries were caused by the act of the defendant or by an instrumentality under the defendant's control"); J. 
FLEMING, supra note 1, at 176, 184; Prosser, Proximate Cause, supra note 1, at 381. Causation-in-fact is the requirement that plaintiff show that his or her injury would not have occurred without the defendant's conduct. E.g., J. FLEMING, supra note 1, at 180; Prosser, Proximate Cause, supra note 1 , at $375-76$. It is a rule of exclusion; if the injury would have occurred even if the defendant had avoided acting as he or she did, then plaintiff cannot recover. Id. at 377-78.

[FN25]. J. FLEMING, supra note 1, at 180; Prosser, Proximate Cause, supra note 1, at 377-78.

[FN26]. RESTATEMENT (SECOND) OF TORTS §§ 431-433 (1965); J. FLEMING, supra note 1, at 182-84; W. PROSSER, TORTS, supra note 1 , at 240-41.

[FN27]. This is so by hypothesis, see supra notes 15-16, 21-22 and accompanying text (causes indistinguishable).

[FN28]. See Estep, Radiation Injuries and Statistics: The Need for a New Approach to Injury Litigation, 59 MICH. L. REV. 259, 263, 270, 274 (1960) (legal effect of "doubling dose").

[FN29]. Independent actors: W. PROSSER, TORTS, supra note 1, at 243-44; see supra notes 34 and accompanying text (alternative liability). Concerted action: id. at 294-98, 314 and cases cited therein; RESTATEMENT (SECOND) OF TORTS §§ 431-433, 876 (1965).

[FN30]. W. PROSSER, TORTS, supra note 1, at 224, 238-44, 284-85 and cases cited therein; Prosser, Proximate Cause, supra note 1 , at 275, 378, 381. See Anderson v. Minneapolis, St. P. \& S. Ste. M. Ry., 146 Minn. 430, 179 N.W. 45 (1920) (innocent and culpable forces combined); Garcia v. Joseph Vince Co., 84 Cal. App. 3d 868, 874-75, 148 Cal. Rptr. 843, 846-47 (2d Dist. 1978) (plaintiff was injured by one of two sabers, which had been commingled; held plaintiff could not use Summers $v$. Tice to shift burden of proof onto defendants). See also J. FLEMING, supra note 1, at 183, 188-89; Owl Drug Co. V. Crandall, 52 Ariz. 322, 328, 80 P.2d 952, 954 (1938); Morales v. House Fire \& Casualty Co., 342 So. 2d 1248, 1250 (La. Ct. App.), cert. denied, 345 So. 2 d 49 (La. 1977) (defendant's contribution must appear more probable than not, in light of other factors that could have caused the accident).

[FN31]. 445 F.Supp. 337, 338 (S.D. Tex. 1978); McCreery v. Eli Lilly \& Co., 87 Cal. App. 3d 77, 83-85, 150 Cal. Rptr. 730, 733-34 (3d Dist. 1978) (strict liability cases); 2 F. HARPER \& F. JAMES, THE LAW OF TORTS §§ 20.1-.6, at 1108-16 (1956) \& SUPP. at 92-104 (1968) (same); RESTATEMENT (SECOND) OF TORTS § 286, at 25 (1965) (negligence per se); Rogers v. Mountain States Tel. \& Tel. Co., 100 Ariz. 154, 162, 412 P.2d 272, 278 (1966). See generally Estep, supra note 28 , at 273-80.

[FN32]. Ybarra v. Spangard, 25 Cal. 2d 486, 489, 154 P.2d 687, 689 (1944); W.PROSSER, TORTS, supra note $1, \S 39$, at 214, 218-24. See McCoid, Negligence Actions Against Multiple Defendants, 7 STAN. L. REV. 480, 482-501 (1955).

[FN33]. This is a prime requirement of a suit grounded in res ipsa loquitur. 25 Cal. $2 \mathrm{~d}$ at 489 , 154 P.2d at 689; W. PROSSER, TORTS, supra note 1, \& 39, at 214; McCoid, supra note 32, at 485. In our paradigms, the defendant will be able to point out a possible-indeed, probablealternative cause, namely a force of nature. For the same reasons, plaintiff will be unable to show that the defendant was in exclusive control of the injury-producing instrumentality, another requirement of res ipsa loquitur. Id.

[FN34]. See Reserve Mining Co. V. EPA, 514 F.2d 492, 514-19 (8th Cir. 1975); cases cited supra note 16 (DES, asbestosis, tobacco, radiation, chemicals); Podgers, supra note 16 (American cases); Soble, supra note 13, at 707-12 (Japanese cases).

[FN35]. The expert only testifies that increased incidence of injury is caused by defendant's 
conduct.

[FN36]. E.g., FED. R. CIV. P. 23(a)(3).

[FN37]. Williams v. Page, 60 F.R.D. 29, 34-35 (N.D. Ill. 1973); Eisman V. Pan Am. World Airlines, 336 F.Supp. 543, 547 (E.D. Pa. 1971); Dolgow V. Anderson, 43 F.R.D. 472, 491-97 (E.D.N.Y. 1968).

[FN38]. E.g., FED. R. CIV. P. 20 (permissive joinder possible if parties-plaintiff assert "any right to relief jointly, severally, or in the alternative").

[FN39]. E.g., Kellenberg v. Beth Israel Hosp., 45 A.D.2d 177, 357 N.Y.S.2d 508 (1974), aff'd, 37 N.Y.2d 719, 337 N.E.2d 128, 374 N.Y.S.2d 615 (1975); C. MCCORMICK, HANDBOOK ON THE LAW OF DAMAGES 117-26 (1935).

[FN40]. See authorities cited supra note 39. See also Hicks v. United States, 368 F.2d 626 (4th Cir. 1966).

[FN41]. Attributed to William of Occam, this principle-that entities should not be multiplied beyond necessity-urges that the simplest rule or theory be adopted consistent with the phenomena or facts to be explained or organized. See, e.g., B. RUSSELL, A HISTORY OF WESTERN PHILOSOPHY AND ITS CONNECTION WITH POLITICAL AND SOCIAL CIRCUMSTANCES FROM THE EARLIEST TIMES TO THE PRESENT DAY 472 (1945).

[FN42]. See infra Part III.

[FN43]. [1946] 1 K.B. 50 (Scott, L.J.).

[FN44]. Bonnington Castings v. Wardlaw, 1956 A.C. 613 (unanimous decision by the House of Lords).

[FN45]. [1952] 1 D.L.R. 1.

[FN46]. Id. at 4.

[FN47]. See generally Pfennigstorf, Environment, Damages and Compensation, 1979 AM. B. FOUND. RESEARCH J. 347, 406-18 (summarizing statutes).

[FN48]. Id.; see Comment, Toxic Substance Contamination, supra note 16, at 59; cf. Soble, supra note 13, at 703, 714, 723, 767-68 (current administrative and legislative mechanisms inadequate for compensating victims of toxic substance pollution).

[FN49]. See, e.g., 7 U.S.C. § 1444(a) (1976); ALASKA STAT. § 46.03.822-.824 (1977); FLA. STAT. ANN. § 403.726 (West Supp. 1982); MD. NAT. RES. CODE ANN. § 8-1409 (1974); sources cited infra notes 50-51; cf. Soble, supra note 13, at 705-09 (discussing difficulty of proving causation in environmental injury cases). In a small number of statutes, the burden of proof with respect to causation is eased. See infra note 51 (use of presumption of causality in Black Lung Act).

[FN50]. 42 U.S.C. § 2210 (1976); Comment, The Irradiated Plaintiff: Tort Liability Outside Price-Anderson, 6 ENVTL L. 858, 858-63 (1976) (discussing the Price-Anderson Act).

[FN51]. E.g., Black Lung Disease Act, 30 U.S.C. § 921(c) (Supp. IV 1980) (providing that a miner who works for ten years in one or more coal mines and incurs black lung disease shall be presumed to have contracted it as a result of his or her work in the mines). 
[FN52]. See supra notes 2-6, 29, 32, 34, 39-40 and accompanying text; Note, Proof of Causation in Multiparty Drug Litigation, 56 TEX.L.REV. 125, 127-31 (1977) [hereinafter cited as Note, Multiparty Drug Litigation] (exceptions permitted in cases of concerted action, common goal, res ipsa loquitur, and "necessity").

[FN53]. Thode, The Indefensible Use of the Hypothetical Case to Determine Cause in Fact, 46 TEX.L.REV. 423, 432 (1968); Note, Multiparty Drug Litigation, supra note 52, at 127-31; see sources cited infra notes $56-57$ and accompanying text.

[FN54]. See sources cited supra note 52.

[FN55]. See infra notes 56-64 and accompanying text (causation-in-fact requirement applied with policy considerations in mind). But see J. FLEMING, supra note 1, at 179 (no social policy is strong enough to warrant imposing liability where but-for causation is absent).

[FN56]. E.g., Malone, Ruminations on Cause-in-Fact, 9 STAN. L. REV. 60, 61-64 (1956) (cause less a physical fact finding than a purposive, evaluative judgment); Pedrick, Causation, The "Who Done It" Issue, and Arno Becht, 1978 WASH. U.L.Q. 645, 654, 657; sources cited infra notes 58-61.

[FN57]. See supra notes 2-6, 29, 32, 34, 39-40 and accompanying text; Note, Multiparty Drug Litigation, supra note 52, at 127-29 (doctrines governing burden of proof on causation respond to considerations of fairness, policy, access, and "necessity").

[FN58]. Malone, supra note 56.

[FN59]. Green, The Causal Relation Issue in Negligence Law, 60 MICH. L. REV. 543, 560-61 (1962).

[FN60]. R. KEETON, LEGAL CAUSE IN THE LAW OF TORTS at vii, 18-20 (1963).

[FN61]. W. PROSSER, TORTS, supra note 1 , at 459.

[FN62]. Calabresi, Concerning Cause and the Law of Torts: An Essay for Harry Kalven, Jr., 43 U. CHI. L. REV. 69, 79-87 (1975) [hereinafter cited as Calabresi, Concerning Cause]; Coase, The Problem of Social Cost, 3 J.L. \& ECON. 1 (1960). See G. CALABRESI, THE COST OF ACCIDENTS (1970); R. POSNER, ECONOMIC ANALYSIS OF LAW 10-12 (2d ed. 1977); Borgo, Causal Paradigms in Tort Law, 8 J. LEGAL STUD. 419, 432 (1979); Rodgers, Negligence Reconsidered: The Role of Rationality in Tort Theory, 54 S. CAL. L. REV. 1, 11 n.44 (1980).

[FN63]. Gelpe \& Tarlock, supra note 9, at 404-07. See J. KRIER, ENVIRONMENTAL LAW AND POLICY: READINGS, MATERIALS AND NOTES ON AIR POLLUTION AND RELATED PROBLEMS 218-21 (1971); Katz, supra note 13, at 607. See generally Pfennigstorf, supra note 47, at 36065 (cost-internalization by polluter a principal maxim in environmental law in U.S. and Western Europe).

[FN64]. Weinrib, A Step Forward in Factual Causation, 38 MOD. L. REV. 518, 523-29 (1975).

[FN65]. These are the principal goals of the system of tort liability, W. PROSSER, TORTS, supra note 1 , at 16-24; F. HARPER \& F. JAMES, supra note 31 , §§ 26.1, 26.5, at 1361-64, 1370-74 (1956); Calabresi, Concerning Cause, supra note 62, at 79-87; Katz, supra note 13, at 607; Pound, The End of Law as Developed in Legal Rules and Doctrine, 27 HARV. L. REV. 195, 233 (1944).

[FN66]. See infra Part III, Section B ("The Proposed Solution"). 
[FN67]. See supra notes 23-51 and accompanying text.

[FN68]. See supra note 63 and accompanying text. Gelpe and Tarlock propose to lower the quantum of proof for establishing cause-in-fact in environmental cases.

[FN69]. In Title VII litigation, the plaintiff seeking to prove discrimination need only establish "disparate impact." The burden then shifts to the employer to demonstrate that the challenged practice was not discriminatory. E.g., Griggs v. Duke Power Co., 401 U.S. 424, 431-32 (1971); Shoben, Probing the Discriminatory Effects of Employee Selection Procedures with Disparate Impact Analysis Under Title VII, 56 TEX.L.REV. 1, 5 (1977).

[FN70]. See description of Paradigms I and II supra text accompanying notes 18-21 (plaintiff must be in zone of risk and must suffer an injury of the type caused by defendant's acts).

[FN71]. Loss spreading is a recognized policy of tort law. See supra note 65 and accompanying text; Posner, Strict Liability: A Comment, 2 J. LEGAL STUD. 205 (1973); Posner, A Theory of Negligence, 1 J. LEGAL STUD. 29 (1972).

[FN72]. For discussions of economic efficiency as a prime goal of tort law, see, e.g., G. CALABRESI, supra note 62; Coase, supra note 62; R. POSNER, supra note 62; Developments in the Law-Class Actions, 89 HARV. L. REV. 1318, 1356 (1976) [hereinafter cited as Class Actions].

[FN73]. The long latency period for some cases of biological causation falling under Paradigm I might pose problems for the deterrence and economic efficiency rationales. If a manufacturer disseminates a harmful agent at time $X$, and the judicial sanction is imposed for the first time only many years later, the result may seem anomalous. How can deterrence and taking safety precautions be furthered by a delayed penalty that the defendant could not have anticipated under rules in effect at time $X$ ?

The harshness of the delayed penalty is mitigated somewhat by the requirement that the actor's conduct, at the time of acting, be known to cause an increase in the rate of injury. See supra notes 15-16 and accompanying text. Tortfeasors will be left with the argument that commission of a known injurious act, not prohibited under then current rules, should be forever immune to tort sanction. This argument seems weak. It would also mean the defeat of all tort cases of first impression, as tort rules could only be adopted prospectively. Plaintiffs would have little incentive to press law reform suits.

[FN74]. Knowledge generation is a key goal of regulatory systems when dealing with technologies that, with further development, may be made safer or more humane. E.g., Soble, supra note 13; Delgado, Active Rationality in Judicial Review, 64 MINN. L. REV. 467 (1980). See Sindell v. Abbott Laboratories, Inc., 26 Cal. 3d 588, 610, 607 P.2d 924, 936, 163 Cal. Rptr. 132, 144, cert. denied, 449 U.S. 912 (1980); Escola v. Coca Cola Bottling Co., 24 Cal. 2d 453, 46168,160 P.2d 436, 440-44(1944).

[FN75]. Cf. C. MCCORMICK, HANDBOOK ON THE LAW OF EVIDENCE 787 (E. Cleary 2d ed. 1972); Cleary, Presuming and Pleading: An Essay on Juristic Immaturity, 12 STAN. L. REV. 5 (1959) (burden of proof often placed on the party with the best access to knowledge).

[FN76]. Tort rules ought to serve the cause of justice. E.g., Calabresi, Concerning Cause, supra note 62 , at 79; W. PROSSER, TORTS, supra note 1 , at 3-4, 15-19.

[FN77]. This result, intuitively obvious, is fortified by analogy to three situations in which intuition or case law support recovery:

1. Conspiracy. Persons who perform wrongful acts in concert with others are punished in both tort and criminal law, in part because society does not want them to escape liability merely because of diffusion of responsibility. W. PROSSER, TORTS, supra note 1, at 294-98; W. LAFAVE 
\& A. SCOTT, HANDBOOK ON CRIMINAL LAW 453-527 (1972). The same insight applies to the case of indeterminate plaintiffs. A wrongdoer who diffuses his or her wrongful act among a group of victims behaves just as reprehensibly as one who joins with others in a criminal venture. One person who harms a group should not escape liability when a group who harms a single victim does not.

2. Spatial comparison. The above reasoning is illustrated by a spatial metaphor. Imagine a Paradigm II situation in which a small group of miscreants negligently throws stones in the direction of a single victim, who is injured when struck by a single stone. Witnesses observe the incident, but are unable to tell which stone struck the victim because of a barrier-a hedge, a row of trees-located near the stone-throwers. Summers v. Tice applies, and the plaintiff can recover against each thrower without proof of specific causation.

Contrast this situation with one in which a single person throws a stone in the direction of a group of persons who are exposed to the same type of injury from a natural source. A barrier again obscures the paths of the stones; the evidence establishes that the thrown stone injured one victim, but not his or her identity. Intuitively, the slight alteration of the facts in this second situation does not alter the claim for relief. Each thrower is equally blameworthy; each victim has an equally strong claim for recovery.

3. Single-victim/many act analogy. Imagine that a single defendant negligently exposes a single plaintiff to repeated risks of injury. The plaintiff is also at risk for the same type of injury from natural causes. The natural causes are more causally efficacious than defendant's acts, so that the probability of a given injury's being attributable to the defendant's conduct is less than 50 percent, say 40 percent. The causes act separately. Over a period of time, the plaintiff suffers several injuries of the type in question.

If the plaintiff were to sue on suffering the first injury, he or she should lose; it would be more likely than not that the injury was caused by natural forces. But if the plaintiff sues after incurring two (or $n$ ) injuries, seeking recovery for only one injury, then he or she presumably should recover. The probability that the defendant has caused at least one injury now exceeds 40 percent. (Assuming that natural and human factors operate independently, the chance that the defendant has not injured the plaintiff is now $.60 \times .60$, or .36. See generally C. MCCORMICK, supra note 75, at 492-93 (illustrating the probability calculation involved)).

It seems reasonable to extend this result to the case of the class whose members are endangered by similar conduct. The "vertical" experience of the individual, over time, duplicates the "horizontal" experience of the class. That the harm is incurred by several persons, rather than one, should not affect the case for liability. It might be argued that defamation law does not afford recovery for defamation of a large group, and that physical harms should be treated no differently. But this argument fails. No recovery is afforded for defamation of a large group, because the members are not considered to have incurred significant damage, W. PROSSER, TORTS, supra note 1 , at 749-51. The same cannot be said here.

[FN78]. By this, it is meant that a causal relationship between the defendant's act and plaintiff's harm (redefined as exposure) would be found. Other causation problems might remain, for example those concerned with proving the extent of consequential damages-lost income, medical expenses, and the like. Cf. Environmental Defense Fund v. Ruckelshaus, 439 F.2d 584, 593 (D.C. Cir. 1971) (element of risk-without proof of actual harm-adequate to sustain injunction in environmental suit); Gelpe \& Tarlock, supra note 9, at 412; Comment, Judicial Attitudes, supra note 16, at 376 (proposing that carcinogenic exposure be regarded as a harm in itself).

In a different context, redefinition of harm was used in Curlender v. Bio-Science Laboratories, 106 Cal. App. 3d 811, 165 Cal. Rptr. 477 (2d Dist. 1980), where a California appellate court for the first time characterized being born with genetic anomalies as a legally compensable harm in a suit brought by the child. In Curlender, a genetic testing laboratory was sued for failure to diagnose Tay-Sachs disease, with the result that a child was born with the disease. Had the test been performed properly, the child-plaintiff would not have been born at all, would not have filed suit, and would not have had a basis (the hypothetical nonexistence) for calculating damages. All earlier courts had refused to permit suit in similar "wrongful life" 
situations. The California court upheld the cause of action, reasoning that existence-plusabnormality is a cognizable harm even if the alternative is nonexistence.

[FN79]. See W. PROSSER, TORTS, supra note 1, § 12, at 49-62 (infliction of mental distress). Recovery is generally permitted for conduct that exceeds the bounds of reasonable behavior, that is calculated to cause serious mental distress, and that does in fact do so. Id. at 56 . The conduct that is punished may be intentional, or "reckless in its deliberate disregard of . . . risks." Id. at 60. Merely negligent infliction of distress without a physical impact or physical manifestation is generally not compensable. Id. at 59.

Some of the cases in our paradigms could be accommodated under theories of intentionally or recklessly created emotional distress. See, for instance, the more than 100 cases filed in Sacramento, California, Superior Court in the period 1979-80 against an anesthesiologist who allegedly committed sexual acts on unconscious female patients during surgery. Some of the complaints allege that the plaintiff was a patient in the hospital, may have been victimized by the anesthesiologist, had been unable to find out whether victimization occurred, and suffered psychological distress as a result. Telephone interview with Mr. Vernon A. Leeper, Program Manager, Enforcement Division, California Board of Medical Quality Assurance, Sacramento, California (Mar. 3, 1980); L.A. Times, June 4, 1980, Part I at 2, col. 5. See also Payton V. Abbott Laboratories, 83 F.R.D. 382 (D.Mass. 1979) (certified a class of DES exposees; case will test whether exposure plus fear of cancer-causation is compensable under theory like that under discussion); Ferrara v. Gallucio, 5 N.Y.2d 16, 21, 152 N.E.2d 249, 252, 176 N.Y.S.2d 996, 999 (1958) (mental anguish for X-ray burns that could become cancerous held compensable). But see Mink v. University of Chicago, 460 F.Supp. 713, 716 n.2, 719 (N.D. Ill. 1978) (fear and anguish of DES-exposed mothers over possible harm to their children held not compensable).

[FN80]. McGhee v. National Coal Bd., [1972] 3 All E.R. 1009 (H.L.), noted in Weinrib, supra note 70, at 523-29. See also RESTATEMENT (SECOND) OF TORTS \& 433 B comments $\mathrm{f}, \mathrm{g}, \mathrm{h}$ (1965) (explaining Summers v. Tice-type alternative liability on the ground that it is defendants' conduct that causes plaintiff's inability to identify the cause of injury); sources cited infra note 91; J. KRIER, supra note 63, at 218-21; J. SAX, DEFENDING THE ENVIRONMENT: A STRATEGY FOR CITIZEN ACTION 136-57 (1971) (burden-shifting reverses our historic preference for resource exploitation by requiring those who modify natural ecosystems to explain and defend their actions); Gelpe \& Tarlock, supra note 9, at 374-88.

[FN81]. Where defendant breaches a statutory provision or a plain common law duty and where "the injury . . . is precisely the sort of thing that proper care . . . would be intended to prevent [the court will] allow a certain liberality to the jury in drawing its conclusion." W. PROSSER, TORTS, supra note 1, at 243 n.53 (citing cases achieving this result by means of "estoppel").

[FN82]. E.g., Gelpe \& Tarlock, supra note 9; Comment, Toxic Substance Contamination, supra note 16 (proposing reduction in stringency with which factual causation requirement is applied in environmental and public-health cases). See also W. PROSSER, TORTS, supra note 1, at 243 n.53; supra notes 64-68 and accompanying text (commentators purport to find sliding-scale approach in courts' treatment of causation-in-fact).

Stubbs V. City of Rochester, 226 N.Y. 516, 526, 124 N.E. 137, 140 (1919), illustrates this approach. The plaintiff, a resident of the city of Rochester, contracted typhoid after the city negligently allowed the water supply to become contaminated. The plaintiff could not trace her own sickness to the contaminated water, however, since there are many causes of typhoid other than contaminated water. Plaintiff could not eliminate these other possibilities. After the water supply became contaminated, the city experienced about a one-sixth increase in the number of typhoid cases over the previous period, about 50 additional cases. The court held that where two or more causes are possible, one culpable, the others not, the plaintiff need only prove defendant's responsibility for her injury "with reasonable certainty." The court found such reasonable certainty in the facts of plaintiff's case and reversed a nonsuit for the defendant. But see Wolf v. Kaufmann, 27 A.D. 281, 282-83, 237 N.Y.S. 550, 551-52 (1920) (plaintiff fell down an unlighted stairway; there were no eyewitnesses or other evidence of the cause of the fall; 
held, action dismissed, as no evidence was presented to eliminate other possible causes of the accident or to make the defendant's negligence in not maintaining a light a more likely explanation of the accident than other competing explanations). The result in Stubbs is open to the criticism that it overcompensates plaintiffs, five-sixths of whom deserve no recovery, and overpunishes the defendant. See infra note 90 and accompanying text (without proration of the type proposed in this Article, simple relaxation of the burden of proof with respect to causation can result in "crushing liability").

[FN83]. In transferred intent, $A$, intending to injure $B$, instead hurts $C$. $A$ is liable to $C$ for an intentional tort. W. PROSSER, TORTS, supra note 1 , at 32. In vicarious liability, the liability of an individual, $B$, who bears a certain relation to $A$ (such as master-servant) is imputed to $A$ for policy reasons. Id. at 458-67.

There seems to exist no theoretical reason why such legal fictions, already used to extend concepts of deterrence and cost-spreading, could not be used in connection with compensation. If vicarious action and transferred intent can be used to hold particular defendants liable once certain facts are shown, it would seem that other factual showings might render plaintiffs compensable, if equally pressing policy grounds urge it.

In either of these established sitautions, something about the relationship among the plaintiff, the defendants, and the act is "realigned" to achieve the goal of holding A liable. Symmetry, as well as a possibly desirable social result, may be achieved by a similar realignment in our paradigms. The element of injury, tortiously caused by the defendant and known to exist somewhere in the plaintiff class, is aligned to coincide with the class representative who prosecutes the suit. This representative, at the outset of the case, satisfies every element of a negligence action except provable loss, see supra note 15-22 and accompanying text. The imputed element completes the picture.

[FN84]. Jury nullification occurs when a jury defies a judge's instructions and returns a verdict against the law, usually to soften the effect of what the members regard as unfair legal doctrine. See, e.g., H. KALVEN \& H. ZEISEL, THE AMERICAN JURY 310-12, 433-35 (1966).

[FN85]. In one view of their function in tort law, punitive damages are awarded to plaintiff as a stand-in for other persons who were also victimized by the defendant but who are unlikely to bring suit. Rodgers, supra note 62, at $11 \mathrm{n} .43$ (discussing allocation of punitive damages in the MER products liability cases).

[FN86]. The award could be used, for example, to establish a clinic or hospital for the treatment of injuries of the type created, or for medical or scientific research aimed at preventing or curing the condition. See infra note 97.

[FN87]. In Insurance Co. of N. Am. v. Forty-Eight Insulations, Inc., 633 F.2d 1212, 1224-25 (6th Cir. 1980), a federal circuit court affirmed a finding by a trial court applying an "exposure" theory to apportion liability among a number of insurance companies for asbestos related injuries. The result held the insurers liable for a pro rata share of the injuries during the relevant exposure period, corresponding to the period of time the insurance was in force.

The theory of recovery discussed in the text would apply similar logic one further step. An insurer, like one of those in INA, would argue that it should be permitted to sue to recover the medical claims for which it was held responsible, in a subrogation action against the tortfeasor.

[FN88]. The number of claims for which recovery would be sought is $90-\mathrm{N}$, supra note 19 . See 16 G. COUCH, CYCLOPEDIA OF INSURANCE LAW § 61.111, at 300-01 (1966) (subrogation permitted where insurer has paid claim that would be legally valid if sued on by the insured). Although there appear to be no reported cases, it would seem that an insurer could sue for claims that it could prove were paid, despite its inability to identify the policyholders who received payment for the tortiously created injury.

[FN89]. See supra note 23 (existing tort mechanisms not fully adequate, but suggesting that 
proposed solution is feasible).

[FN90]. See Shavell, An Analysis of Causation and the Scope of Liability in the Law of Torts, 9 J. LEGAL STUD. 463, 481 (1980) (policy of causation rules is to avoid "crushing liability" for defendants and to induce them to take greater care). In our paradigms, crushing liability could occur if the plaintiffs' burden of proof is lowered with respect to causation, see supra text accompanying notes $68-69$, but he or she is permitted to recover full damages.

[FN91]. Burdens of proof, including those governing causation, commonly are allocated according to notions of policy, necessity, and ease of proof. See, e.g., Haft v. Lone Palm Hotel, 3 Cal. 3d 756, 772-73, 478 P.2d 465, 475-76, 91 Cal. Rptr. 745, 765-66 (1970) (burden shifted where defendant's negligence resulted in lack of a witness by whose testimony plaintiff might have proved her case); J. FLEMING, supra note 1 at 188-89; C. MCCORMICK, supra note 75, at 785-87; Prosser, Proximate Cause, supra note 1, at 386; RESTATEMENT (SECOND) OF TORTS $\$$ 433B(2)-(3) \& comments a, c, f (1965) (burden of proof follows policy); Cleary, supra note 75; Note, Multiparty Drug Litigation, supra note 64, at 127-31.

Suppose the rise in incidence of the injury is from 100 to 250 cases, an increase that, according to expert statisticians and epidemiologists, cannot be accounted for by chance. If expert testimony establishes that the incidence has more than doubled, then each plaintiff will prefer to sue individually, as causation can now be made to appear more probable than not. The defendant's potential liability is 250 cases.

Could a defendant take the initiative and sue for a declaratory judgment that it is only liable for 150 injuries, thus compelling proration among the 250 possible claimants? Fairness to defendants would suggest that this possibility should be preserved. Many defendants will hesitate to invoke it, of course, for fear of flushing out claims that might not be brought. But see In re Northern Dist. of Cal. "Dalkon Shield" IUD Prods. Liab. Litig., 526 F.Supp. 587, 596 (N.D. Cal. 1981) (defendant corporation succeeded in compelling formation of a class consisting of all persons who had claims for punitive damages against it arising out of the use of defendant's allegedly defective birth control device).

[FN92]. That is, he could show that the figure is smaller than 190-N. See supra note 19 (calculation of number of victims).

[FN93]. If he or she is successful at showing the existence of two or more defendants, then neither paradigm applies, and plaintiff's suit should be dismissed, unless the plaintiff can: (i) identify the class members victimized by the other defendant and drop them from the suit; (ii) show that both human defendants are liable under existing law pertaining to concurrent tortfeasors, see supra notes 2-6 and accompanying text; W. PROSSER, TORTS supra note 1, at 291-98; or (iii) convince the court to combine the reverse-Sindell with the Sindell theory, so as to allow the suit to proceed as an action by an indeterminate plaintiff class against an indeterminate defendant class, infra Part IV, Section D. The latter alternative poses grave management difficulties, of course. Id.

[FN94]. In current law, proration of liability among defendants is carried out pragmatically. If there exists any reasonable basis for assigning particular damages to particular defendants, this will be done. W. PROSSER, TORTS, supra note 1, at 313-14; see Insurance Co. of N. Am. V. Forty-Eight Insulations, Inc., 633 F.2d 1212, 1225 (6th Cir. 1980) (holding insurers liable for pro-rata share of damages in asbestosis suit).

It would seem that proration among plaintiffs in our paradigms is just as defensible as it is in the classic tort contexts in which it is done in connection with defendants. See generally $\mathrm{W}$. PROSSER, TORTS, supra note 1, at 317-23 (apportionment). Cf. Atomic Energy Damages Act, 42 U.S.C. $\S \S 2012,2210$ (1976) (providing for proration of claims of victims of atomic accident if amount of claims exceeds $\$ 500$ million plus available private insurance coverage); MER Cases, Roginsky v. Richardson-Merrell, Inc., 378 F.2d 832, 838-40 (2d Cir. 1967) \& Toole v. Richardson-Merrell, Inc., 251 Cal. App. 2d 689, 711-16, 60 Cal. Rptr. 398, 414-17 (1st Dist. 1967) (allocating right to recover punitive damages in cases of injury to many persons). 
Methods by which a damage award will be calculated and distributed are discussed infra note 96.

[FN95]. See generally FED. R. CIV. P. 23(e) (requiring judicial approval before class action settled); id. 23(c)(2) (requiring notice to class members in certain types of class suits). While a class action (or other multiple plaintiff) action would not be required to be brought in cases falling under our paradigms, any plaintiff bringing an individual suit would suffer early dismissal or summary judgment. See supra notes 23-28 and accompanying text.

The use of the class action vehicle is thus integral to the substantive remedy proposed here. For the view that this interplay between substantive policy-effectuation and procedural channels is an inevitable and desirable aspect of class actions, see Class Actions, supra note 72, at 1353:

Class action procedures assist courts in giving full realization to substantive policies in two ways. First . . . they open courts to claims not ordinarily litigated . . . . Second . . . they enable courts to see the full implication of recognizing rights or remedies [thereby] judging precisely what outcomes of litigation would best serve the policies underlying causes of action. . . . Through class action procedures, moreover, the interests of absentees . . . are more likely to be given their due.

These considerations seem especially true here.

Must the plaintiff join all the class members in his or her suit? Sindell only required that the defendant-class contain a "substantial" share of the manufacturers of DES. This would seem sufficient here as well.

[FN96]. Thus, in the first paradigm, if each member of the exposed class suffered a loss of one thousand dollars, and the evidence shows that the defendant is responsible for $90-\mathrm{N}$ such losses, see supra note 19 , the class as a whole will recover $(90-\mathrm{N}) \times \$ 1,000$. Each member will receive $1 / 190$ of this amount, minus the costs of the suit.

[FN97]. A number of solutions seem possible including:

(1) class-wide estimation of the total damages, e.g., Bigelow v. RKO Radio Pictures, 327 U.S. 251, 264 (1946); Pettway v. American Cast Iron Pipe Co., 494 F.2d 211, 260-63 (5th Cir. 1974);

(2) sampling or averaging to arrive at an approximate damage figure, Petteway $v$. American Cast Iron Pipe Co., 494 F.2d at 263 n.154; Shapiro, Processing the Consumer Claim, 41 ANTITRUST L.J. 257, 270-73 (1972);

(3) distributions to the class as a whole (by setting up a clinic or other treatment facility, for example), e.g., Carlisle v. Eisen \& Jacquelin, 52 F.R.D. 253, 264 (S.D.N.Y. 1971), rev'd, 479 F.2d 1005 (2d Cir. 1973), vacated and remanded on other grounds, 417 U.S. 156 (1974); Bebchick v. Public Util. Comm'n, 318 F.2d 187, 203-04 (D.C. Cir.), cert. denied, 373 U.S. 913 (1963) (established fund for benefit of transit riders after proof that PUC overcharged customers). See generally Class Actions, supra note 72, at 1524-36 (discussing situations in which fluid recovery is, or is not, appropriate). Suppose that the injuries attributable to defendant and those attributable to natural causes are undifferentiable but defendant believes, nevertheless, that he or she can demonstrate a bias toward "cheap" injuries in the group of victims injured by his or her action. He or she should be permitted to attempt to prove such a bias, and if a skewing is proved, the damage award should be adjusted accordingly.

[FN98]. Class Actions, supra note 72, at 1356 (class action device forces defendants to confront the full cost of their acts, thereby promoting social efficiency).

[FN99]. See supra notes 66-70 (compensation interest); Class Actions, supra note 72, at 1337 (overarching policy of law, achieving relief as congruent as possible with the class injured, facilitated by class actions, as contemplated herein).

[FN100]. E.g., Podgers, supra note 16. 
[FN101]. E.g., Sindell v. Abbott Laboratories, 26 Cal. 3d 588, 603 n.17, 607 P.2d 924, 931 n.17, 163 Cal. Rptr. 132, 139 n.17 (1980) (discussing and dismissing due process objection).

[FN102]. Podgers, supra note 16; Shavell, supra note 90 (avoidance of "crushing liability").

[FN103]. Some (but not all) cases falling within the first paradigm might seem amenable to legislation or administrative treatment. See, e.g., Green, supra note 16, at 505-06; Soble, supra note 13; Comment, Manufacturers' Liability Based on a Market Share Theory: Sindell v. Abbott Laboratories, 16 TULSA L.J. 286, 303-05 (1980); Comment, Toxic Substance Contamination, supra note 16. Radiation, air pollution, food and water contamination cases, and cases arising from improperly marketed drugs or foodstuffs might present the technical complexity that makes agency, rather than court, treatment attractive. Sindell itself illustrates a problem (an unsafe medicine) falling, as an initial matter, within the jurisdiction of an existing agency. Still, agencies rarely have the power to award damages, see Posner, A Theory of Negligence, $1 \mathrm{~J}$. LEGAL STUD. 29, 48-49 (1972) (tort sanction more effective than administrative regulation); often become "captives" of the industries they regulate; and are currently viewed disfavorably as examples of intrusive, centralized government. See also Peck, The Role of the Courts and Legislatures in the Reform of Tort Law, 48 MINN. L. REV. 265, 297-98 (1963) (arguing that case-by-case tort law approach can provide a type of test-tube experimentation, results of which may eventually be incorporated in the form of legislation).

[FN104]. E.g., W. PROSSER, TORTS, supra note 1, at 236-41.

[FN105]. Id. at 18, 236-41; see sources cited supra note $1,24-26$ (defining cause-in-fact requirement).

[FN106]. The principal reasons were that: (1) as between an innocent plaintiff and a group of negligent defendants, the burden of proof with respect to causation should be placed on the latter; (2) tort rules should be flexibly adapted to enable them to deal with problems of modern technology; and (3) the defendants were better able than plaintiff to bear or distribute costs. $\underline{26}$ Cal. 3d at 610-12, 607 P.2d at 936-37, 163 Cal. Rptr. at 144-45.

[FN107]. Thus seen, they are simply intermeddlers stirring up litigation in which they have no standing.

[FN108]. See supra notes 94-96 and accompanying text (members of indeterminate plaintiff classes recover only partial damages).

[FN109]. Cf. 26 Cal. 3d at 611-13,607 P.2d at 936-38, 163 Cal.Rptr. at 145-46 (California Supreme Court's discussion of the related question of when causal indeterminacy lies in the defendant class).

[FN110]. Certain forms of completely probabilistic proof have been disapproved. See C. MCCORMICK, supra note 75, at 493-98; Kaye, Probability Theory Meets Res Ipsa Loquitur, 77 MICH. L. REV. 1456, 1474-83 (1979).

[FN111]. Statistics are used at the outset to show that an increase in the number of victims is greater than that which is likely to result from chance. Other possible causes are then eliminated, resulting in the conclusion that defendant's action-independently known to be negligent-has caused $190-\mathrm{N}$ victims. See supra note 19 . This use of evidence is thus unlikely to result in fastening blame on a completely innocent person; it is not used to pick the defendant "out of a crowd." Cf. People v. Collins, 68 Cal. 2d 319, 325-26, 438 P.2d 33, 36-37, 66 Cal. Rptr. 497, 500-01 (1968), in which a prosecutor attempted to prove that a couple charged with the crime was the same couple observed at the scene of the offense by computing the combined probability that a randomly chosen couple would have the following characteristics: partly yellow automobile, man with mustache, girl with ponytail, girl with blond hair, Negro man with beard, 
interracial couple in car. The case is discussed in C. MCCORMICK, supra note 75, at 493-97. See also Tribe, Trial by Mathematics: Precision and Ritual in the Legal Process, 84 HARV. L. REV. 1329, 1349-50 (1971) (probabilistic evidence for identification purposes often rejected because of potential unfairness toward defendants who are unlucky enough to bear certain characteristics).

[FN112]. Compare Pritchard v. Liggett \& Myers Tobacco Co., 295 F.2d 292, 294-96 (3d Cir. 1961) (plaintiff attempted to show that (i) cigarette smoking tends to cause lung cancer; (ii) he suffered lung cancer; (iii) he smoked cigarettes; (iv) therefore, the cigarettes were probably the cause of his disease) with cases falling under Paradigm I. In Paradigm I, the plaintiff is not attempting to show such a connection between general conduct of the type engaged in by defendant and his or her injury. Rather, the plaintiff is only attempting to show a connection between defendant's action and an increased incidence of injury of a type known to result from conduct like that of the defendant. The latter type of inference can be much more secure than the former because of the much larger number of persons in the plaintiff class. An increase in the frequency of an event from 100 to 190 , see supra notes 18-19 and accompanying text, may support a more confident inference of causation than an increase from zero to one.

[FN113]. Cf. People v. Collins, 68 Cal. 2d 319, 327-28, 438 P.2d 33, 38, 66 Cal. Rptr. 497, 502 (1968); Tribe, supra note 111, at 1336, 1361-66 ("dwarfing the soft variable").

[FN114]. Cf. 68 Cal. 2d at 329-31, 438 P.2d at 40-41, 66 Cal. Rptr. at 503-04; Tribe, supra note 111 , at $1364-66$.

[FN115]. Cf. Kaye, supra note 110, at 1481-82.

[FN116]. Cf. 68 Cal. 2d at 328-29, 438 P.2d at 39, 66 Cal. Rptr. at 503; Tribe, supra note 111, at $1366-68$.

[FN117]. The next subsection considers the objection that the proposal would have too many applications-that a reverse-Sindell doctrine could be combined with Sindell rules, resulting in endless liability.

[FN118]. See supra notes 15-22 and accompanying text (use of reverse-Sindell principle requires that plaintiff be unable to determine whether his or her injury resulted from natural or human causation).

[FN119]. Where proof of causation is possible, the plaintiff can recover fully. In the model proposed, only proportional relief is possible, see supra notes 91-99 and accompanying text.

[FN120]. See supra note 14 and accompanying text (Medfly spraying cases may exemplify Paradigm II). Paradigm II requires simultaneously acting forces, one human, the other natural, each causing a known number of undifferentiable injuries, see supra notes 21-22 and accompanying text. This paradigm of "mechanically proved causation" would apply if the number of pitted windshields and paint jobs before and after Medfly spraying were known with great accuracy.

[FN121]. See supra notes 15-20 and accompanying text ("Statistically Proved Causation"). This paradigm requires a number of injuries of a type that can result either from natural or human causes, acting without synergy: that the injuries be causally indeterminate, i.e., not assignable to one category or the other by observation or investigation; that the defendant be the only possible human cause; and that the population, mode of risk, and other variables be stable enough to permit an epidemiological or statistical calculation of the increased number of injuries above a background level.

[FN122]. But see infra Part IV, Section D ("Combining Both Theories: Indeterminate Plaintiff 
Versus Indeterminate Defendants").

[FN123]. This is so because epidemiological inferences about causation are most easily drawn in such situations. E.g., B. MCMAHON \& T. PUGH, supra note 19, at 207-83; J. MAUSNER \& A. BAHN, supra note 19 , at 63-110, 307-30.

[FN124]. E.g., J. MAUSER \& A. BAHN, supra note 19, at 296-99.

[FN125]. Sindell-type suits will be rare because they require causal indeterminacy and a group of defendants who behaved identically-a situation not likely to arise with great frequency. Reverse-Sindell suits require causal indeterminacy and a group of plaintiffs who suffered injury in a uniform manner. These, too, should be relatively rare.

[FN126]. The Sindell approach requires a plaintiff known to have been injured by human tortfeasors; the reverse-Sindell approach requires a single human defendant known to have caused a determinable number of injuries. Therefore, neither doctrine fits this hypothetical situation.

[FN127]. These costs include the commitment of possibly massive judicial resources to the trying of the suit, the risk of "strike" suits filed for their settlement or harrassment value, and the risk that juries will simply prove unable to deal with the technical complexities of such cases. All such problems are present, of course, in the Sindell and reverse-Sindell situations, standing alone. The combined effect of uniting both indeterminate plaintiffs and defendants may exceed the legal system's ability to adapt. Cf. Shavell, supra note 90, at 494 (causation rules exist, in part, to keep litigation costs within reasonable bounds).

70 CALR 881

END OF DOCUMENT 